\title{
Invited by God onto the worship stage: Developing missional communities through participation in Theo-drama
}

\begin{tabular}{|c|c|}
\hline \multicolumn{2}{|l|}{$\begin{array}{l}\text { Authors: } \\
\text { Ian A. Nell }{ }^{1} \\
\text { Neil Meyer }{ }^{2}\end{array}$} \\
\hline \multicolumn{2}{|c|}{$\begin{array}{l}\text { Affiliations: } \\
{ }^{1} \text { Department of Practical } \\
\text { Theology and Missiology, } \\
\text { Stellenbosch University, } \\
\text { South Africa }\end{array}$} \\
\hline \multicolumn{2}{|c|}{$\begin{array}{l}{ }^{2} \text { Uniting Presbyterian Church } \\
\text { of Southern Africa, } \\
\text { South Africa }\end{array}$} \\
\hline \multicolumn{2}{|c|}{$\begin{array}{l}\text { Correspondence to: } \\
\text { lan Nell }\end{array}$} \\
\hline \multicolumn{2}{|c|}{$\begin{array}{l}\text { Email: } \\
\text { ianell@sun.ac.za }\end{array}$} \\
\hline \multicolumn{2}{|c|}{$\begin{array}{l}\text { Postal address: } \\
171 \text { Dorp Street, Faculty } \\
\text { of Theology, Stellenbosch } \\
\text { University, Stellenbosch } \\
7600 \text {, South Africa }\end{array}$} \\
\hline \multicolumn{2}{|c|}{$\begin{array}{l}\text { Dates: } \\
\text { Received: } 22 \text { Apr. } 2013 \\
\text { Accepted: } 01 \text { Aug. } 2013 \\
\text { Published: } 01 \text { Oct. } 2013\end{array}$} \\
\hline \multicolumn{2}{|c|}{$\begin{array}{l}\text { How to cite this article: } \\
\text { Nell, I.A. \& Meyer, N., 2013, } \\
\text { 'Invited by God onto the } \\
\text { worship stage: Developing } \\
\text { missional communities } \\
\text { through participation in } \\
\text { Theo-drama', Verbum et } \\
\text { Ecclesia } 34(1) \text {, Art. \#840, } \\
8 \text { pages. http://dx.doi. } \\
\text { org/10.4102/ve.v34i1.840 }\end{array}$} \\
\hline \multicolumn{2}{|c|}{$\begin{array}{l}\text { Copyright: } \\
\text { (C) 2013. The Authors. } \\
\text { Licensee: AOSIS } \\
\text { OpenJournals. This work } \\
\text { is licensed under the } \\
\text { Creative Commons } \\
\text { Attribution License. }\end{array}$} \\
\hline \multicolumn{2}{|l|}{ Read online: } \\
\hline 回的回 & $\begin{array}{l}\text { Scan this QR } \\
\text { code with your } \\
\text { smart phone or } \\
\text { mobile device } \\
\text { to read online. }\end{array}$ \\
\hline
\end{tabular}

When the front of the church begins to resemble a stage and the preacher, musicians and other leaders act like performers whilst the congregation takes on the role of an audience, then something is wrong with worship. But not only with worship: something is wrong with the church. A church longing to be missional - that is, a church in which all Christians are participants in the mission of God - needs to express that participation in its worship. Theological dramatic theory shows us how the Trinity acts out a grand narrative in creation, redemption and glorification, and invites us to participate in the Story being performed. This same narrative can be present in worship and can invite our immediate participation. But this cannot happen if either God or the congregation is relegated to the role of mere audience. However, when the Story is told and performed in worship and when the worshipping community is able to participate alongside the Trinity in the Theo-drama of worship, then worship takes on the ability to form that community missionally. Worship is a habit repeated week after week; therefore, its power to transform a community into a missonal congregation is immense.

\section{Introduction}

At the recent General Assembly (2012) of the Uniting Presbyterian Church of Southern Africa (UPCSA) the assembly adopted a set of mission priorities which includes 'supporting the development of missional congregations' (UPCSA 2012:376-398). In the UPCSA's wrestling with the question of how to make the Missio $D e i^{1}$ a reality in being church, it is interesting how easily participants forget that we have within the Reformed tradition a classical order of service which, if harnessed, has the potential to build within worshippers the habits that could form precisely such missional congregations. Yet ministers are unfortunately woefully ill-prepared due to their unfamiliarity with the shape of the liturgy itself and their ignorance of its power to form character within communities.

Militating against a rediscovery of the beauty and formational potential of the liturgy is the belief, popular amongst many in the UPCSA, that liturgy is old-fashioned and that the future of worship lies in making it more entertaining, especially for those of the younger generation whom the denomination would like to evangelise. Many congregations look admiringly (perhaps even enviously) at the highly-polished musical performances of a church like Hillsong and similar churches that excel in stage-show worship, and assume that by emulating their ability to entertain the crowds their worship would be better. But entertainment and character formation are not the same things.

\section{Problem statement}

In many churches and denominations worship is increasingly seen as a form of religious entertainment. Churches aim to be 'seeker-sensitive' (Hybels \& Hybels 1995:41) to attract the un-churched and try to offer worship styles that compare favourably with the type of musical entertainment current in the secular marketplace. Many churchgoers for their part tend to judge churches on their ability to entertain. The problem is that the analogy of church and theatre or church and entertainment dissolves, so that church is theatre and worship is entertainment. When this happens, members are encouraged to treat the church as consumers treat other forms of entertainment. They sit on the outside looking in and judging the worship, whilst implicitly or explicitly also judging the mission of the church and everything else that the church does. 'A ritual place that sustains passivity during worship mirrors a church community where the congregants are spectators in all other affairs' (Vosko 2009:6). This is the opposite of being a missional community, where church members and communities are engaged in the mission of the church themselves.

1.Missio Dei literally means the 'mission of God'. In missiological discussions since the 1952 Willingen conference of the International Missionary Council, the term has come to refer to the idea that mission is not first a function or activity of the Church, but an attribute of God (Bosch 1991:389-390). 'Missional' is the related adjective used to describe the approach to mission that takes seriously the idea that mission begins with God's activity in the world - activity into which the Church is invited to join. It further implies the idea that every Christian and every Christian community is sent by Jesus with the Gospel to those in their surrounding culture. This means that mission is not limited to those few 'professional' missionaries sent on overseas mission nor is it limited to the formal activities of the church, but also takes place in the ordinary secular business of the world (Newbigin 1989:230). 


\section{Research question}

In this article, the plan is to investigate the question: Will worship experiences that engage the participation of the worshippers be able to transform them missionally, as individuals and communities find their stories reflected and challenged in the light of the overarching Theo-drama of God's creation, redemption and glorification of the world? This question can further be broken into three sections:

- Is Theo-drama ${ }^{2}$ a valid metaphor for describing the interaction between the Trinity and the people of God in worship ${ }^{3}$ ?

- How important is the congregation's participation ${ }^{4}$ in worship and how are the role divisions in worship to be understood according to the analogy of the theatre? Who are the actors and who is the audience?

- How can missional formation be achieved or promoted by the participation of the congregation in the Theodrama of worship?

The overall purpose of this article is therefore to investigate a practical way to utilise and interpret the shape of the liturgy, so that its power to form and transform communities to become missional can be realised. In so doing the authors hope to open the way for others to make the same discovery.

\section{Research methodology}

This article is carried out within the framework of practical theology and therefore makes use of the four tasks of practical theological interpretation, namely the empirical, the interpretive, the normative and the pragmatic. ${ }^{5}$ The biggest emphasis however will be on the third task, applying concepts such as Theo-drama, missio Dei and participation, to the question of how communities ought to be formed missionally through worship. This will involve a literature study of some of the issues related to worship, mission and experiential learning.

\section{Behind the stage}

In an insightful talk entitled Free Market Jesus, Donald Miller (2009), author of Blue Like Jazz, traces the way in which the church has historically modelled herself and her buildings

2.Theo-Drama is a term that was developed by Hans Urs von Balthasar in a series of books published in the early 1980s. Theological dramatic theory takes seriously the narrative or dramatic way that God reveals Godself. God is seen as acting first within the inner relationships of love inside the Trinity, but secondarily, also in relation to the inner relationships of love inside the Trinity, but, secondarily, also in relation to the world through acts of creation, redemption and glorification. Theo-drama also the larger Story of the Trinity.

3.In its broadest sense worship refers to a sense of awe in the presence of the magnificent, the frightening or the miraculous. In many church settings today the term is given an extremely narrow meaning, relating only to the music played and sung in church services, as in the terms 'praise and worship' or 'worship band'. In this article we use the term to describe the corporate acts of worship which take place (mostly) in churches and (mostly) on Sundays. However, we use the term to refer to the whole act, including prayers, proclamation, hymns, sacraments, lessons, silence and so on, and not only to the musical portion.

4.Participation (koinonia) is used in two senses in this article. At a basic level, it means simply the act of taking part in an activity, such as a worshipper taking an active part in the performance of the liturgy. We also expand this meaning to include the part in the perfor Grek conce Trinity through their inclusion or adoption in Christ.

5.Dingemans (1996), Heitink (2003) and Osmer (2008) all refer to these different tasks, albeit with different terminology. on the dominant powers of the day. In the Middle Ages the architecture of the grand cathedrals mimicked to some extent the splendour of castles, so that the house of God resembled the homes of the powerful princes and kings. During the Enlightenment as universities became the seats of power in a world awakening to learning and empirical truth, churches began to take on the shape of lecture-halls with central pulpits and pews arranged in rows as in a classroom. Then as the Industrial Revolution gained ground and the 'Corporation' became all powerful, the church began to model herself on 'big business', with church leaders dressing like CEO's and marketing replacing evangelism.

Unfortunately, further consideration of Miller's analogies goes beyond the scope of this article, but it is important to note that his historical survey stops short of being able to reflect critically on the very 'stage' on which the speaker himself is standing when delivering the talk. The DVD clearly shows Miller standing on a stage in an auditorium-style worship space so typical of the shape of many churches built in the last 40 years. ${ }^{6}$ The analogy with the theatre is unmistakable. In a world where entertainment is king, the church has once more modelled itself on the power of the day. Could this theatrical model of worship lie at the root of the church's inability to turn her adherents into missional agents?

The idea of a theatrical or dramatological analogy for the work of God in the world is not a new one. In the early 1980s, Hans Urs von Balthasar already introduced his theory of TheoDrama in a series of books on Theological Dramatic Theory. This line of theology has recently been taken up fruitfully by other authors including Rick Osmer (2005) and Kevin Vanhoozer (2005). These authors point to the transformative potential of this approach, especially as congregations find their own stories within the Theo-Drama of God's story (Osmer 2005:203). Yet, it is one thing to recognise the drama involved in God's Story, but quite another to see the Church's worship as analogous with a theatrical performance. As to the latter, Jeanne Kilde (2002:22) traces the shift in American evangelical worship towards a staged event to the revivalist meetings of the early 1800 s.

In the case of the development of the auditorium church, this process began with a series of radical revisions in ritual practices made by evangelical preachers during the height of the revivals known as the Second Great Awakening, which swept the northern and central United States during

6. Both authors have witnessed this trend in their respective denominations (Dutch Reformed Church of South Africa [DRC] and Uniting Presbyterian Church in Southern Africa [UPCSA]). Examples of churches that have been built with stages rather than Africa [UPCSA]). Examples of churches that have been built with stages rather than
chancels or that have had their pulpits removed and replaced with stages within chancels or that have had their pulpits removed and replaced with stages within
the DRC include the 'KruisKerk' student community in Stellenbosch, Vredenlust in Bellville and Parow-Welgelegen. Within the UPCSA the unvarying design of churches built since the 1970s (and even 1960s) has been of a wide elevated stage incorporating the pulpit set to one side, the Table central and the choir or music group set to the other side, facing the congregation. Examples of this design include St Giles Presbyterian Church in Orchards, St Mungo's United Church in Bryanston, Trinity Presbyterian Church in Edenvale and Somerset West United Church where even the Table has been moved to the side to incorporate the worship band at centre-stage centre-stage. Moreover, it has been the authors experience of or with more charismatic, Pentecostal and independent churches that these have been designed even more explicitly on the model of an auditorium with a stage. Examples of these would include Rhema Church in Johannesburg, His People in Cape Town, St Jame Church in Somerset West and many others. These churches include not only an elevated stage and musicians facing the congregation in the style of performers, but also stage lighting and darkened seating areas with plush cinema-style chairs. 
the 1820s and 1830s. To engage ever-larger audiences in the spiritual message of salvation and to encourage their participation in revival meetings, revivalists like Charles Finney initially adopted spellbinding oratory and dramatic delivery techniques. A similar experimentation with ritual space - that is, with the Protestant church building itself was the natural outgrowth of the desire to increase audience participation and to extend the revival as widely as possible; yet it led to consequences that the revivalists could not have anticipated.

In the Uniting Presbyterian Church in Southern Africa we find the trend, especially in predominantly White and Western congregations, that churches built in the past 40 years have had the almost unvarying design of a raised platform at one end of a rectangular building, often referred to as the 'stage', on which are placed pulpit, table, font and choir (or music group). They all face the congregation whose members are seated in neat rows facing forward as in a theatre. But is the theatre a valid metaphor for worship? ${ }^{7}$ We begin by considering whether Theo-Drama can serve as a valid model for doing theology.

\section{Theo-Drama as a model for doing theology}

Drama as a category for understanding theology (theological dramatic theory) was first developed fully by Hans Urs von Balthasar in a series of books on the subject published in the early 1980s. Since then there have been several authors who have used this dramatological approach in a variety of ways to deal with the 'story' of God as it relates to, for example, doctrine (Vanhoozer 2005), Scripture (Bartholomew \& Goheen 2004), ethics (Wells 2004) and catechism (Osmer 2005).

It is not the purpose of this article to deal fully with the subject of Theo-Drama, nor to tease out and compare all the different forms it has taken. We simply wish to point out the broad aim of this approach to theology and then to look more closely at one example of how it can be applied to an area of ministry before considering its specific application to the topic of liturgy and worship.

To begin with, the broad aim of a dramatological approach to doing theology is to take seriously the narrative or dramatic way in which God reveals Godself and thereby to invite the readers to find their own stories within the larger story of God. In the words of Von Balthasar (1994):

... we discern the unity of 'glory' and the 'dramatic'. God's glory, as it appears in the world - supremely in Christ - is not something static that could be observed by a neutral investigator.

7.When we speak of a valid metaphor we have in mind a fresh and creative way of speaking about worship in line with Paul Ricoeur's definition of a metaphor. 'In The Rule of Metaphor, Ricoeur argues that is because there is a linguistic productive
imagination that generates and regenerates meaning through the power of metaphoricity to state things in new ways. For him, fresh metaphors, metaphors that have not been reduced to the commonplace, reveal a new way of seein their referents. They creatively transform language. Thus they are not merely retorical ornaments. They have genuine cognitive import in their own right and are untranslatable without remainder into literal language' (see Dauenhauer \& Pellauer 2012).
It manifests itself only through the personal involvement whereby God himself comes forth to do battle and is both victor and vanquished. If this glory is to come within our range at all, an analogous initiative is called for on our part. (p. 12)

N.T. Wright (1991:18) offers a helpful insight into how exactly this 'finding our own story in God's Story' might work by considering the ways in which a story might be said to possess authority. One option is that we could observe the actions of the characters and then be encouraged to follow their example. Another option would be to see the story as setting up a generalised ethos for us to follow. Wright (1991) rejects both these options as being too vague. Instead he proposes a third model:

Suppose there exists a Shakespeare play whose fifth act had been lost. The first four acts provide, let us suppose, such a wealth of characterization, such a crescendo of excitement within the plot, that it is generally agreed that the play ought to be staged. Nevertheless, it is felt inappropriate actually to write a fifth act once and for all: it would freeze the play into one form, and commit Shakespeare as it were to being prospectively responsible for work not in fact his own. Better, it might be felt, to give the key parts to highly trained, sensitive and experienced Shakespearian actors, who would immerse themselves in the first four acts, and in the language and culture of Shakespeare and his time, and who would then be told to work out a fifth act for themselves. (p. 18)

Wright then applies this model to the Theo-drama revealed in Scripture. He identifies the five acts of the play as follows: (1) Creation, (2) Fall, (3) Israel, (4) Jesus and (5) the Final act in which the Church currently finds herself, with the New Testament being the first scene of this final act. He sees our interaction with the entire drama as analogous with the actors he imagines in the Shakespearian production. The extant story acts as our authority insofar as it sets the tone, characterisation and direction of the plot, and we are called to 'offer something between improvisation and an actual performance' as we work out our part in the final act (Wright 1991:19).

\section{Osmer's dramatological model}

In his book The Teaching Ministry of Congregations, Osmer (2005) chooses a dramatological approach when developing the normative framework according to which he plans to develop a model for the teaching ministry. He begins by laying out some of the principles developed by Von Balthasar for understanding how 'serious theatre' works.

Firstly, there is the reason why people go to serious theatre. They do so, according to Von Balthasar, for two reasons: (1) because they hope that the dramatic tensions of their own lives will be reflected in the drama; in other words, that the patterns of their own lives will be mirrored in such a way that they will be able to interpret them more clearly and (2) they hope that the drama will offer them a solution for or an insight into the tensions they face.

Secondly, there is the fact that in the case of the Theo-Drama, those involved in the Christian life are not merely spectators or audience, but are in fact actors in the drama with particular roles to play. 
In addition, there is the idea that the roles given to these 'actors' (i.e. those engaged in the Christian life) are analogous to the 'active receiving' of actors in a play. The actors receive their roles from the author, yet the success of their performance depends on their action - their ability and skill to bring their particular role to life. In other words, instead of the roles being part of a deterministic script, they are part of the creative unfolding of the story (Osmer 2005:200-201).

When he then turns to the story of the Theo-Drama itself, Osmer leans heavily on the Trinitarian theology of Jürgen Moltmann. He seems particularly attracted by the way in which Moltmann pictures God as an open system ${ }^{8}$ - open to the suffering of Creation and open to the possibilities of the future - and the potential this openness creates for interaction between God as author and chief actor in the Theo-Drama and human beings as co-actors. The drama thus depicted falls into four Trinitarian acts:

- Act 1: Before the curtain rises.

- Act 2: Creation by the Father through the Son in the Holy Spirit.

- Act 3: Redemption by the Son in the Spirit to the Father.

- Act 4: Glorification by the Spirit through the Son to the Father.

These are Trinitarian acts because it is quite clear that at each stage Osmer emphasises the primary role played by God, or rather the interactive roles played by the three Divine Persons of the Trinity. This then is Theo-Drama, not simply in the sense that it has been authored by God, but in the sense that it is the Drama of God, the Drama that takes place first and foremost within the inner life of the Trinity. This is an important factor to bear in mind when considering our role in the Theo-Drama (Osmer 2005:204-206).

So, in Act 1 we see the pure inner life of the Trinity, described as a perichoretic dance that takes place between the three persons of the Trinity, or perhaps we do not see this dance, for it takes place 'behind the curtain' as it were. The emphasis here falls on the distinct personhood of each member of the Trinity, following Moltmann's social doctrine of the Trinity in which the 'three Divine persons are bound together in a community of mutual love' (Osmer 2005:205). We see this dance of love continued in the three remaining acts as a different member of the Trinity takes the lead in each act: in Creation the Father leads, in Redemption the Son does, and in Glorification the Spirit comes to the fore. Yet each act is firstly a dance between these Divine actors and only secondly a dance in which we are invited to join.

When Osmer (2005) comes to applying the 'story' of this Theo-Drama to a dramatological model for catechesis, he does so on the basis of five principles summed up in the following definition of catechesis:

Catechesis is an interpretive activity undertaken by congregations and their individual members who see themselves as

8. We accept that Moltmann's view of the world as a system open to God and God as a Being open to the world is not universally accepted; however, we would argue that the value of this view in the present context is its ability to illuminate one possibility for how God is able to invite human participation in the unfolding of the future. participants in the Theo-drama of the triune God and are seeking to better understand their roles in this drama by deepening their understanding of Scripture and Christian tradition. (p. 237)

Interpretive activity: Catechesis helps us find new meaning and understanding in the Scriptures and traditions as we allow them to address our lives and our world. Through the application of practical reasoning we interpret both the texts (of Scripture and tradition) and the contexts (of our lives). The point here seems to be that the application is not necessarily linear or literal, but demands careful, rational interpretation on the part of the catechist (Osmer 2005:238).

Undertaken by congregations and their individual members: Catechesis helps individuals find meaning in their own lives in close relation to God and God's Story. But it is taught within the context of a faith community, which is being built together into a congregation that also has a communal life and purpose to embody its calling as God's people. In other words, there is more at stake than just teaching a hundred individuals how to live in relation to God. There is a simultaneous goal of establishing a congregation which, in the words of Leslie Newbigin (1989:227), as 'the only hermeneutic of the gospel' is a group of people who believe the gospel and live by it. Such a community, and not merely a group of transformed individuals, is the real goal of catechesis (Osmer 2005:238).

Who see themselves as participants in the Theo-drama of the triune God: The purpose of catechesis is to lead congregations and their members beyond text and tradition towards finding their own identity, mission and vocation as God's people in the world. It does so by challenging them to see how the Theo-drama expressed in Scripture and tradition extends beyond these texts to God's involvement in our world today (Osmer 2005:238).

Seeking to better understand their roles in this drama: Having discovered their roles, catechesis helps congregations and their members to 'play out' those roles with integrity. Here Osmer returns to Von Balthasar's analogy of actors 'actively receiving' their roles. The Theo-drama of Creation, Redemption and Glorification is a story of which we gain an understanding through catechesis and we then enter the stage to play our parts in it. Yet if we take seriously God's openness to others and to the future, then the roles we play cannot be understood as set parts in a mechanical system of providence; our own creativity, freedom and choices determine in part how our roles will be played out (Osmer 2005:238).

By deepening their understanding of Scripture and Christian tradition: The sources of Christian faith (Scripture and tradition) are engaged with 'in ways that are analogous to the "mirror function" of serious drama'. Just as members of an audience go to the theatre in the hope that the tensions in their own lives will be reflected and that they will find some insights or solutions, so catechists approach their studies in the hope that Scripture and tradition will mirror their lives in the world (Osmer 2005:239). 


\section{Towards a dramatological model for worship}

We come now to a consideration of how a dramatological model can be developed for worship. Before we do so we need to note a number of important differences between worship and catechism, doctrine, ethics, or any of the other areas in which Theo-drama has found fruitful application.

Firstly, it should be made clear that unlike catechism, worship is not primarily didactic. The purpose of worship is not to teach us anything or to grow us in any way. Worship is an end in itself (Dawn 1995:80). Its purpose is to worship God. The fact that it has the power to form us spiritually is secondary to this main task. Everything that follows with regard to the formative power of worship is therefore said with this fact at the back of our minds. Nevertheless, because it is a repeated habit that brings us into the actual experience of a relationship with God, worship does offer an immense opportunity for formation and transformation. As Marva Dawn (1995) expresses so eloquently:

My major concern for the Church has to do with worship, because its character-forming potential is so subtle and barely noticed, and yet worship creates a great impact on the hearts and minds and lives of a congregation's members. Indeed, how we worship both reveals and forms our identity as persons and communities. (p. 4)

Secondly, and closely linked to the first point, is the fact that unlike with catechism, doctrine or ethics, the way in which Theo-drama interacts with worship is much more immediate. In ethics, for example, we may hear the story of the Theodrama and then be left to apply it (according to the authority described by Wright above) to ethical decisions we have to make. In worship, however, although what we experience is applicable to the rest of our lives, at least part of the application is immediate - we do not only imagine how we might participate in the Theo-drama, in worship we actually participate in the Theo-drama then and there. Moreover it is not only our participation that is immediate, but God's too. In worship God acts. In worship we do not merely hear about God's role in the Theo-drama, we experience it.

The third qualification that must be made is that the shape of the story told through the liturgy of worship is not necessarily the same as the four-act shape described in Osmer's Theodrama. That is not to say that worship tells a different story, or that the characters are different, but merely to point out that the same story can be retold in a variety of ways. Indeed, we have already seen how the dramas described by N.T. Wright (five acts following the biblical-historical story of God) and Osmer (four acts following Moltmann's Trinitarian history of salvation) provide us with two differing ways of telling the same story of the Divine-human Theo-drama.

Finally, there is the problem that arises out of the fact that, unlike the other applications of Theo-drama listed above, in the case of worship we are dealing with an activity that actually looks like a dramatic performance. There are characters (worship leader, choir, preacher, etc.) who have particular lines to speak and actions to perform. Moreover these actions take place in front of a congregation, which can be likened to the 'audience' in a theatre performance. As we will see, whilst these similarities with theatrical performances are to some extent helpful in understanding the dynamics of Theo-drama, they also bear certain inherent dangers for misunderstanding the respective roles of the participants.

\section{Osmer's five dramatological principles applied to worship Worship as an interpretive activity}

Where the primary texts of catechism are the Scriptures and tradition, in worship they are the ritual, the liturgy, the hymns and the Scriptures. Each of these 'texts' is open to interpretation by the worshipper and each has the potential for shaping the way the worshipper in turn interprets his or her own life. Of course, whether or not the worshippers actually do engage in such interpretation depends on such factors as:

- the skill of the worship leader to invite interpretation (i.e. not merely following the liturgy by rote)

- whether the congregation is taught the skills of interpretation (appropriation, integration, praxis learning and informed judgement)

- the space given in worship for thoughtful reflection and whether or not the worship is relevant (i.e. hymns that are not prohibitively archaic, sermons that help to link the Scriptures to life, and so on).

\section{Worship as a task for individuals and community}

Whereas private individual worship is also a valid form of devotion, in the present discussion we are focussing only on the type of corporate public worship found in church gatherings. Here, as in the case of catechism, there is of course a sense in which individuals participate in public worship and gain certain individual benefits as a result. There is a serious danger, though, when the congregation is regarded and approached as no more than an audience of gathered individuals.

Corporate worship is just that: corporate. It is not an activity for individuals but for a community and there are serious deficiencies in worship if a community is not formed in the process. To explain this in more detail let us consider just one element of worship, namely the sacrament of Holy Communion. Whilst it is true that the sacrament has many benefits for individual believers, such as spiritual consolation, commemoration of the death and resurrection of Christ, and assurance of the individual's communion in Christ with God the Father, this is in fact only half of the story. For the sacrament is also a celebration of our incorporation into and reconciliation with the community gathered around and in Christ, and as Paul makes clear in 1 Corinthians 12, such a celebration without actual reconciliation and participation in the community so gathered is deficient. 


\section{Worship as participation in the Theo-drama of God}

As in catechesis worship invites us not only to hear the story of the Divine-human Theo-drama, but also to consider how that Theo-drama goes beyond the texts to God's ongoing involvement in the world, the Missio Dei. As mentioned above, worship does even more than this by bringing us into immediate contact with the Theo-drama itself as God acts in worship. In fact, worship can be our most conscious participation in the Theo-drama, since in worship we are not merely asked to consider how Theo-drama might apply to our lives but we are actually told 'Here is God speaking' (in the reading of Scripture) and 'Here is God acting' (in the sacraments).

\section{The goal of worship is to help us better understand our role in the drama}

We saw that the primary goal of worship is the worship of God. Therefore, any other goal, such as helping worshippers to find their role in the Divine-human Theo-drama, must be secondary. Of course, at one level these two goals do amount to the same thing, since our primary role in the Theo-drama is to worship God, at least if one takes seriously the teaching of the Westminster Shorter Catechism that the chief end of man (sic) is 'to glorify God, and to enjoy him forever!'

On a much more specific level, though, Von Balthasar's analogy of roles being actively received by actors in a play can be applied to worship. Through Word and Sacrament, hymns and ritual, worship retells the Story of the gospel and invites us to play our roles as individuals and community. Within the liturgy itself our roles may be fairly formal and 'scripted' if you like, but at least in the commission at the end of the service the indication is clear that how we respond and 'play out' our received roles in the way we carry our experience of worship into the world with us (living as missional communities) is open to the possibilities of our own freedom, choices, creativity and, of course, obedience.

\section{Worship deepens our experience of the drama}

Osmer's definition of catechism (2005:237) concludes by stating that catechism deepens our 'understanding of Scripture and Christian tradition'. As already mentioned, the primary 'texts' of worship include such elements as ritual, liturgy and hymns along with Scripture. But, more importantly, worship, unlike catechism, is not so much aimed at deepening our understanding as deepening our experience of God and God's Story. Having said this, we do believe that the analogy with the 'mirror function' of serious drama can also be applied to worship. It is possible that people go to church, as they go to the theatre, in the hope of seeing the tensions of their own lives reflected and in the hope of gaining insights or solutions to those tensions. It is possible, but not inevitable. Before coming to the conclusion we do have to answer the following question.

\section{Is worship experienced as 'serious drama' or as escapist entertainment?}

The analogy taken from Von Balthasar and used by Osmer in the discussion above of the 'mirror function' of serious drama is a compelling one; however, it hinges on the assumption that worship may be compared to 'serious drama'. We therefore work with the argument that whilst the intention of most liturgies (certainly the more classical forms of the liturgy) is to offer a serious engagement with the drama of the gospel and whilst many believers do attend worship with the hopes described in Von Balthasar's analogy, there is also another, perhaps more powerful analogy at play when many think of the 'theatre' of worship today. We are referring here to theatre or drama as escapist entertainment:

When the congregation becomes an audience and its worship a vaudeville act, then the Church finds itself at risk: the death of

faith and Christian character is a clear possibility. (Dawn 1995:13)

The danger here lies in two directions, the one sociological, the other liturgical and evangelistic. On the one hand there is the problem that art, drama and music play a very different role in society today from the role that the arts had in former years. The sheer volume of art (be it visual, verbal, musical or drama), information and other distractions we have access to is overwhelming and has turned most of us into consumers, making it almost impossible for us to do any more with what we see of the art than to just be distracted by it and then move on to the next stimulus.

Not only the volume, but the media through which we receive our art and information have become much faster, catchier, and 'bittier'. We catch snippets of news on the web, hear sound-bites on the radio news and watch TV shows that seldom have segments longer than 10 minutes interspersed with ad-breaks featuring a series of 30 second 'spots'. Today information and art entertain us. This is very different to the sacred role that art, drama and music played in ancient societies, or the 'mirror function' that theatre has in Von Balthasar's analogy of 'serious drama'.

The point is that worship has certain external similarities with a theatrical performance. When people today observe or experience a service of worship, what metaphor do they bring with them to 'read' that experience? If they have been brought up to 'consume' art as entertainment, they will approach even a worship service with its artistic flourishes of ritual, music and oratory with an eye to being entertained, rather than with the hopes of having the personal tensions of their lives reflected or 'solved'.

The second danger lies in how the church responds to this change in society. In an effort to remain relevant, the church is often tempted to give people what they want and if entertainment is what they're after, then that is what we will give them. Returning to the metaphors of power suggested by Donald Miller, if the Medieval church said, 'We have a better King than the king' and the Enlightenment church 
said, 'We have a better classroom than the University', then maybe the 21st-century church is saying, 'We have better entertainment than MTV.'

We started by asking how the congregation participates in the Theo-drama of worship. From what has been discussed we would venture the following conclusions: Firstly, it seems to us that the metaphor of drama or theatre must be used very carefully in relation to worship. Because of the increasing physical similarities between worship spaces and concert halls, there exists a real danger that theatre may become more than a metaphor for what goes on in worship. In the end, worship is not theatre. In addition, when the place of worship takes the form of an auditorium with a stage and seating for an audience, how can we avoid assuming that those on stage are the actors and those in the plush seats are the audience?

Secondly, the foregoing discussion has made it clear that if we do continue to use the metaphor of drama, we need to take a more nuanced look at such matters as the theory of theatre, the role of God in worship and the work of the people in worship. A simple labelling exercise (listeners are actors, God is audience) does not take into account all the complexities of the interactions that take place during worship.

\section{Conclusion}

We want to conclude by linking worship as 'serious drama' with the challenge of missional formation, ${ }^{9}$ and therefore to its power to transform a community into a missonal congregation. For this process the following needs to be present in worship:

- Missional formation takes place through regularly repeatable practices (such as weekly worship) and not through the cerebral transfer of knowledge.

- Missional formation involves bringing our own stories into close connection or alignment with God's Story.

- Missional formation demands discernment to be able to hear in God's Story how our own stories are either disrupted or affirmed, and to become aware of the new reality to which God calls us as a result.

- Missional formation calls us to participation in the larger Theo-drama of God's Story.

There are several factors that could inhibit the ability of the practice of corporate worship to be missionally formative, and the same is probably true of any exercises or discipline designed to promote missional formation. In the case of worship, then, we want to link it to three forms of grounding. ${ }^{10}$

9 .With respect to missional formation a lot could be learned from theories on experiential learning. Practical theologian, Thomas Groome, wrote extensively on the topic; see Groome (1999).

10.Another theory on experiential learning is the so-called U-theory of Otto Scharmer (2009). Scharmer (2009:436-442) adds three 'root principles' of grounding of Theory $U$ learning that must be in place in order to connect us to the 'deepest source' as we go through the process and so allow the process to truly transform us. He names the three root principles: intentional grounding, relational grounding, and authentic grounding.
Intentional grounding:

- If worship is not a regularly repeated practice (i.e. if the worshipper does not become familiar with the rhythms of worship), then it is doubtful that the experience will be transformative (the entire weight of missional formation is too much for a single worship service to bear).

- If the classical order of service ${ }^{11}$ is not followed, then it is unlikely that the experience will be transformative. This is not to say that another well-designed order would not work in similar fashion, but rather that one would have to ensure that the basic movements of praxis learning are all in place.

- If the order is followed without continuity and coherence, then missional formation is unlikely to occur. Missional formation is a deeply intentional process. The mere progression through the steps of the classical liturgy (or any other liturgy or missional discipline) will not necessarily result in transformation.

Relational grounding:

- It is unlikely that true missional formation will take place if worshippers engage with the liturgy without the formation of a worshipping community. This is not to deny that private worship has any value, but rather to affirm that missional formation is by definition community-forming. Recall that the mission of God is fundamentally about the sending of love to others God's mission is the establishment of loving community.

Authentic grounding:

- If the worshippers are not authentically engaged as participants in the process of the liturgy, it is unlikely that they will be missionally formed. The critical issue here is the connection between our stories and God's Story.

- If worshippers do not take concrete opportunities to develop their worship beyond the liturgy (i.e. to expand the prototypes of transformation experienced in worship to their daily lives), then missional formation halts at the Church door and never truly engages with the missio Dei in the world beyond.

Theo-drama is therefore a valid metaphor for describing not only the interaction between the Trinity and the creation but also more specifically the interaction between the Trinity and the people of God in worship. The transformative power of worship as Theo-drama rests heavily on both the participation of the congregation and the understanding that God is active in worship. It is therefore necessary to rethink the roles of God, preachers and worship leaders, and congregation in the drama of worship. To relegate either the congregation or God to the position of mere audience is to reject the missional principle according to which God is the primary Actor in the missio Dei and we, the Church, are invited to participate alongside God.

When the church participates alongside God in the Theodrama of worship, then the classical shape of the liturgy

11.By the "classical shape' of the liturgy we are not referring to any particular book of order or common prayer, but rather to the basic outline or shape that worship follows, which is: Gathering worship (including Call to Worship, Prayers of Approach and Adoration, Confession and Declaration of Grace), The Word of Approach and Adoration, Confession and Declaration of Grace), The Word
(including Scripture and Sermon), Response (including Creed and Offertory), Communion (including Sacraments and Intercessions), Commission. 
assists in missional formation by providing a 'script' or 'plot' according to which our stories can be brought into contact with God's Story. In this way our stories are taken up into God's Story, we find our own stories mirrored there and we are able to be transformed through a process of experiential or praxis learning. Moreover, the fact that this liturgical experience is repeated as a weekly habit means that it is a powerful transformational discipline.

\section{Acknowledgements Competing interests}

The authors declare that they have no financial or personal relationship(s) that may have inappropriately influenced them in writing this article.

\section{Authors' contributions}

I.A.N. (Stellenbosch University) was the study leader in the project and made conceptual and structural contributions. N.M. (Uniting Presbyterian Church of Southern Africa) did the literature study and wrote the article.

\section{References}

Bartholomew, C.G. \& Goheen, M.W., 2004, The drama of Scripture: Finding our place in the biblical story, Baker Academic, Grand Rapids.

Bosch, D., 1991, Transforming mission: Paradigm shifts in theology of mission, Orbis Books, New York.
Dauenhauer, B. \& Pellauer, D., 2012, 'Paul Ricoeur', in E.N. Zalta (ed.), The Stanford Encyclopedia of Philosophy, viewed 23 January 2013, from http://plato.stanford. edu/archives/win2012/entries/ricoeur/

Dawn, M., 1995, Reaching out without dumbing down, Eerdmans, Grand Rapids.

Dingemans, G.D.J., 1996, 'Practical theology in the academy: A contemporary overview', The Journal of religion, 82-96.

Groome, T.H., 1999, Christian religious education: Sharing our story and vision, JosseyBass, New York. PMCid:PMC2269298

Heitink, G., 2003, Tussen 'oprit 57' en 'afslag 03': De weg, het landschap en de praktische theologie, VU Boekhandel/Uitgeverij, Amsterdam.

Hybels, L. \& Hybels, B., 1995, Rediscovering church: The story and vision of Willow Creek Community Church, Zondervan, Grand Rapids.

Kilde, J.H., 2002, When church became theatre: The transformation of evangelical architecture and worship in nineteenth-century America, Oxford University Press, Oxford. PMid:12020203

Miller, D., 2009, Free market Jesus, Christian Art Publishers.

Newbigin, L., 1989, The gospel in a pluralist society, Eerdmans, Grand Rapids.

Osmer, R., 2005, The teaching ministry of congregations, Westminster John Knox Press, Louisville.

Osmer, R., 2008, Practical Theology: An introduction, Eerdmans, Grand Rapids.

Scharmer, C., 2009, Theory U: Leading from the future as it emerges, Barrett-Koehler, San Francisco. PMid:19589989

Uniting Presbyterian Church of Southern Africa (UPCSA), 2012, Supplementary papers for the 10th General Assembly, Unpublished.

Vanhoozer, K.J., 2005, The drama of doctrine: A canonical-linguistic approach to Christian theology, 1st edn., Westminster John Knox Press, Louisville.

Von Balthasar, H.U., 1994, Theo-Drama: Theological dramatic theory. IV: The action, Ignatius Press, San Francisco.

Vosko, R.S., 2009, 'Shaped by what we shape: How the environment for worship affects ritual behaviour', Liturgy 25(1), 4-12. http://dx.doi. org/10.1080/04580630903209744

Wells, S., 2004, Improvisation: The drama of Christian ethics, Brazos Press, Grand Rapids.

Wright, N.T., 1991, 'How can the Bible be authoritative?', Vox Evangelica 21, 7-32. 